\title{
Relationship between the female attendance pattern and pup growth rate in the South American sea lion (Carnivora)
}

\author{
Massimiliano Drago ${ }^{1,2}$, Luis Cardona ${ }^{1}$, Valentina Franco-Trecu ${ }^{3}$, Federico G. Riet-Sapriza ${ }^{4}$, \\ Enrique A. Crespo ${ }^{5,6}$, Néstor García ${ }^{6}$, Pablo Inchausti ${ }^{2}$ \\ ${ }^{1}$ IRBio and Department of Evolutionary Biology, Ecology and Environmental Science, University of Barcelona, \\ Av. Diagonal 643, 08028 Barcelona, Spain. \\ (MD) (Corresponding author) E-mail: m.drago@ub.edu. ORCID-iD: https://orcid.org/0000-0003-2764-9849 \\ (LC) E-mail: luis.cardona@ub.edu. ORCID-iD: https://orcid.org/0000-0002-7892-1323 \\ ${ }^{2}$ Departamento de Ecología y Evolución, Centro Universitario Regional Este (CURE), Universidad de la República \\ (UdeLaR), C/ Tacuarembó s/n, 20000 Maldonado, Uruguay. \\ (PI) E-mail: pablo.inchausti.f@gmail.com. ORCID-iD: https://orcid.org/0000-0002-3498-5894 \\ ${ }^{3}$ Departamento de Ecología y Evolución, Facultad de Ciencias, Universidad de la República (UdeLaR), Iguá 4225, 11400 \\ Montevideo, Uruguay. \\ (VF-T) E-mail: vfranco-trecu@fcien.edu.uy. ORCID-iD: https://orcid.org/0000-0003-1791-010X \\ ${ }^{4}$ Laboratorio de Ecología Molecular de Vertebrados Acuáticos (LEMVA), Departamento Ciencias Biológicas, Facultad de \\ Ciencias, Universidad de los Andes, Carrera 1E No 18A - 10, Bogotá, Colombia. \\ (FGR-S) E-mail: frietsapriza@gmail.com. ORCID-iD: https://orcid.org/0000-0002-6568-2802 \\ ${ }^{5}$ Universidad Nacional de la Patagonia San Juan Bosco, Bvd. Brown 3051, 9120, Puerto Madryn, Chubut, Argentina. \\ (EAC) E-mail: kike.crespo@uv.es. ORCID-iD: https://orcid.org/0000-0001-9216-7817 \\ ${ }^{6}$ Laboratorio de Mamíferos Marinos, Centro Nacional Patagónico (CENPAT-CONICET), Blvd. Brown 29150, \\ 9120 Puerto Madryn, Argentina. \\ (NG) E-mail: garcia@ @enpat-conicet.gob.ar. ORCID-iD: https://orcid.org/0000-0002-3178-7534
}

\begin{abstract}
Summary: Changes in the duration and frequency of foraging trips by female otariids may result in changes in the duration and frequency of lactation bouts and hence influence pup growth rate, unless females modify milk energy density and/or the total amount of milk delivered depending on the trip duration. To test this hypothesis on South American sea lions, we measured two attendance pattern components (foraging trip and haul-out duration) and three diving behaviour components of nursing females (dive time, bottom time and number of dives per $\mathrm{h}$ ) at two different rookeries in Uruguay and Argentina, the composition and energy density of their milk, and the growth rate of their pups. Female foraging trip and haul-out durations depended on pup sex and weight, whereas milk energy density depended on female body mass and foraging trip durations. By contrast, the three dive variables were independent of female body mass or pup sex. Pup growth was also independent of the foraging trip and haul-out duration, with pup sex as the only significant variable. This suggests that individual differences in female foraging behaviour play a minor role in determining pup growth rates during the first three weeks after birth.
\end{abstract}

Keywords: Otaria flavescens; Otaria byronia; pup growth rate; lactating female; milk composition; diving; foraging trip.

Relación entre el patrón de cuidados maternales y la tasa de crecimiento de las crías en el león marino sudamericano (Carnivora)

Resumen: Las hembras lactantes de los otáridos difieren en la duración y frecuencia de sus viajes de alimentación, lo que puede afectar a la duración y frecuencia de los episodios de lactancia de las crías y, en consecuencia, a su crecimiento, a menos que las hembras modifiquen la densidad energética de la leche y/o la cantidad total de leche suministrada en función de la duración del viaje. Para comprobar la validez de esta hipótesis en los leones marinos sudamericanos, medimos dos componentes del patrón de cuidado maternal (la duración de los viajes de alimentación y la duración del tiempo en tierra) y tres componentes del comportamiento de buceo (tiempo de buceo, tiempo en el fondo y número de inmersiones por hora) de las hembras lactantes en dos colonias diferentes de Uruguay y Argentina, así como la composición y densidad energética de su leche y la tasa de crecimiento de sus crías. Las duraciones de los viajes de alimentación y del tiempo en tierra de las hembras dependieron del sexo y peso de las crías, mientras que la densidad energética de la leche dependió de la masa corporal de la hembra y la duración de los viajes de alimentación. Por el contrario, las tres variables de buceo no estuvieron relacionadas con la masa corporal de la hembra ni con el sexo de la cría. El crecimiento de las crías también fue independiente de la duración del viaje de alimentación y del tiempo en tierra, siendo el sexo de las crías la única variable significativa. Esto sugiere que las diferencias individuales en el comportamiento de alimentación de las hembras juegan un papel menor en la determinación de las tasas de crecimiento de las crías durante las tres semanas inmediatamente posteriores al parto.

Palabras clave: Otaria flavescens; Otaria byronia; tasa de crecimiento de las crías; hembras lactantes; composición de la leche; buceo; viajes de alimentación. 
Citation/Como citar este artículo: Drago M., Cardona L., Franco-Trecu V., Riet-Sapriza F.G., Crespo E.A., García N., Inchausti P. 2021. Relationship between the female attendance pattern and pup growth rate in the South American sea lion (Carnivora). Sci. Mar. 85(2): 8190. https://doi.org/10.3989/scimar.05128.008

Editor: D. Oro.

Received: September 8, 2020. Accepted: February 1, 2021. Published: May 28, 2021.

Copyright: () 2021 CSIC. This is an open-access article distributed under the terms of the Creative Commons Attribution 4.0 International (CC BY 4.0) License.

\section{INTRODUCTION}

Parental care is the main component of the reproductive cost in birds and female mammals, and offspring survival is expected to be more strongly influenced by parent foraging efficiency than breeding periodicity or clutch/litter size (Clutton-Brock 1991, Davies et al. 2012). For mammalian females, lactation is the most energetically demanding activity during the breeding cycle, even more than gestation (Gales et al. 1996, Higgins and Gass 1993). As a consequence, the foraging efficiency of females is expected to have a major impact on pup growth and survival at weaning (Georges and Guinet 2000, Jeanniard du Dot et al. 2017). In land-breeding marine mammals such as otariids (eared seals), lactating females behave as central place-foragers, alternating feeding trips to sea with suckling bouts on land during the long lactation, which can be upwards of a year for some species (Schulz and Bowen 2004). Generally, otariids inhabit continental margins with high primary productivity, likely to satisfy the energy requirements during key foraging periods with high energy demand (Gentry 2009, Webber 2014).

The growth rate of otariid pups depends largely on three major maternal care components: the balance between the length of the foraging trips and that of the suckling haul-outs (i.e. the maternal attendance pattern), the amount of milk delivered to the pup, and the quality of the milk delivered (Gentry et al. 1986, Georges et al. 2001, Georges and Guinet 2000). Females can modify their behaviour in different ways to promote the growth rate of their pups according to food availability; consequently, pup growth rate should reflect the foraging tactic adopted by the mother (Gentry et al. 1986). The length of foraging trips depends on the distance to foraging grounds, as well as on prey availability, individual foraging efficiency and pup age, the latter considered as a factor that affects the pup fasting ability (Boyd et al. 1994, Costa 2008, McHuron et al. 2016). In general, females spend proportionally more time ashore nursing their pups when foraging trip duration is shorter (Georges and Guinet 2000, Jeanniard du Dot et al. 2017, McHuron et al. 2016), which has been reported to result in faster pup growth rates (Gentry and Kooyman 1986, Georges and Guinet 2000, Jeanniard du Dot et al. 2017). However, females involved in long foraging trips targeting richer foraging grounds may balance a lower attendance frequency by increasing milk fat content or total milk delivery (Arnould and Boyd 1995, Arnould and Hindell 1999), which may explain the positive correlation between the length of foraging trips and the pup absolute mass gain reported in some studies (Guinet et al. 1999).
The South American sea lion (Otaria flavescens) inhabits the coasts of South America, and its $3500 \mathrm{~km}$ range in the southwestern Atlantic spans from warm temperate Uruguay to sub-Antarctic Tierra del Fuego (Cappozzo and Perrin 2009). Previous research has revealed that the growth and survival of South American sea lion pups are influenced by colony size (Campagna et al. 1992, Drago et al. 2011), but little is known about the influence of female foraging behaviour on these parameters. Certainly, foraging trips became longer in Peru during intense El Niño events (Soto et al. 2004, 2006), and some components of diving behaviour influence the rate of energy expenditure in other otariid females (Arnould et al. 1996, Costa and Gales 2000), but little is known about the effect of individual variability in foraging behaviour on pup growth rate (McHuron et al. 2016). In this paper we assessed female body mass and quantified two variables of the maternal attendance pattern (duration of the foraging trips and haul-outs) and three variables of diving behaviour (dive time, bottom time and dives per $\mathrm{h}$ ) to determine their effect on milk energy density and pup growth rate in the western South Atlantic, hypothesizing that longer and more frequent female foraging trips reduce the duration and frequency of lactation bouts and the growth of pups.

\section{MATERIALS AND METHODS}

\section{Study area and sample collection}

Sampling was performed during the 2009 and 2015 breeding season (January-February) at Isla de Lobos (Uruguay) and Isla Arce (Argentina), respectively (Fig. 1). Both islands are located $\sim 9 \mathrm{~km}$ from the mainland, in two areas differing greatly in marine primary productivity (Acha et al. 2008, Miloslavich et al. 2011, Rivas et al. 2006), which is higher around Isla de Lobos than around Isla Arce (Fig. 1). Isla de Lobos, with an area of 0.41 $\mathrm{km}^{2}$, supports about 1200 sea lions (Franco-Trecu 2015) and Isla Arce, with an area of $0.45 \mathrm{~km}^{2}$, supports about 900 (Crespo EA unpublished data). However, samples were collected from two reproductive areas containing a total of 180 and 150 individuals of both sexes and all development stages (pup, young, subadult and adult) for Isla de Lobos and Isla Arce, respectively.

On both islands, lactating sea lion females and their pups were captured during the second and third week of January, when females resumed feeding after parturition. We used hoop nets to randomly capture 10 lactating females in Uruguay and 12 in Argentina, along with their $13( \pm 2)$ day-old suckling pups (Uruguay, 4 males and 6 females; Argentina, 4 males and 8 females). The age of pups (Table 1) was known be- 


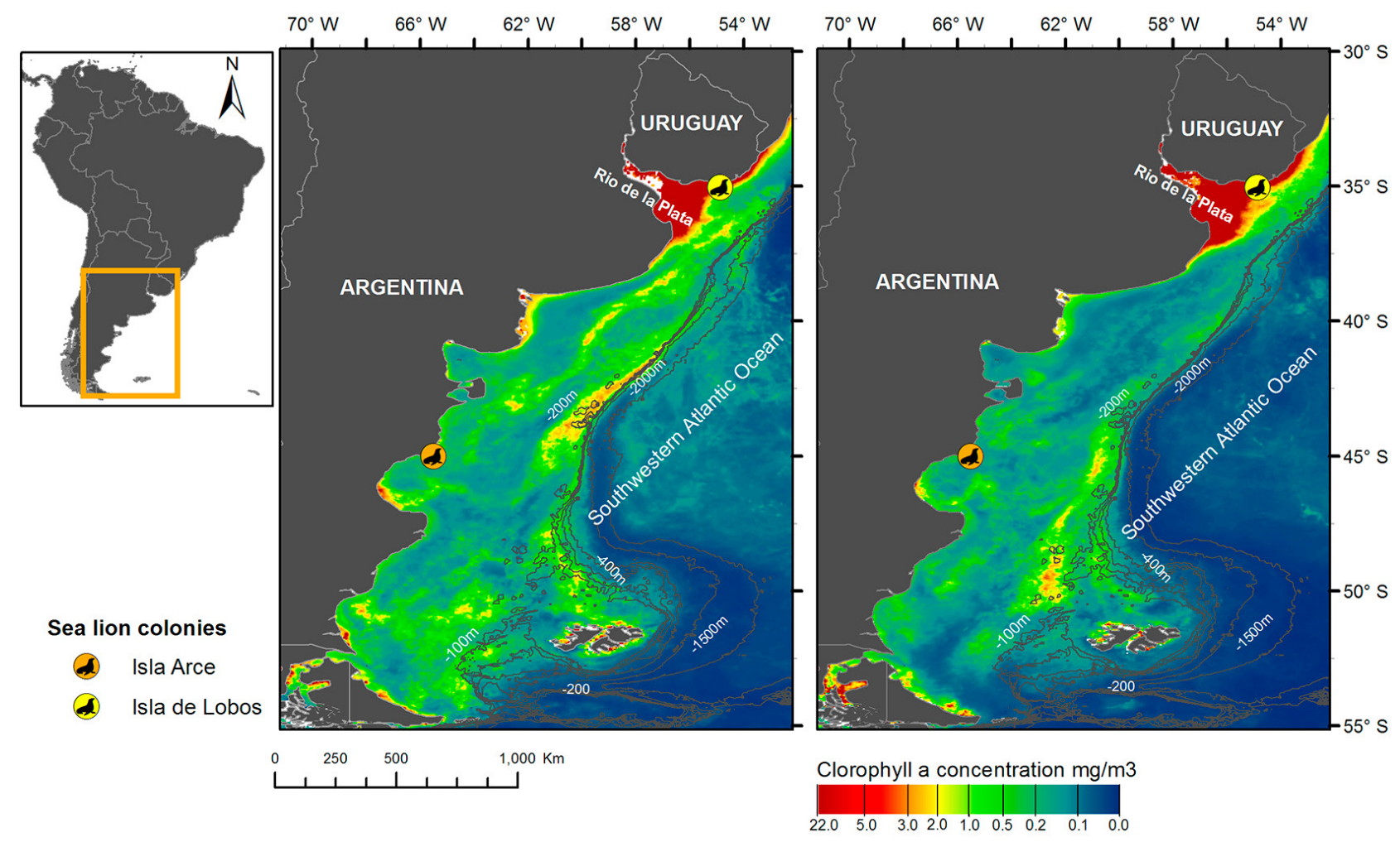

Fig. 1. - Location of South American sea lion breeding colonies studied in Uruguay (Isla de Lobos) and Argentina (Isla Arce) and the annual average values of chlorophyll- $a$ concentration in the 2009 (left panel) and 2015 (right panel) sampling years (NASA 2018).

Table 1. - Female body size, milk energy density, pup age, sex and body size, pup specific growth rate (SGR) and descriptors of the foraging and haul-out behaviour of lactating South American sea lion females from breeding colonies in Uruguay (Isla de Lobos) and Argentina (Isla Arce). Superscripts denote females that are heavier than average.

\begin{tabular}{|c|c|c|c|c|c|c|c|c|c|c|c|c|c|c|c|c|c|c|c|}
\hline \multirow[t]{2}{*}{$\frac{\overrightarrow{0}}{0}$} & \multirow[t]{2}{*}{ 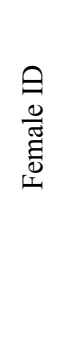 } & \multirow[t]{2}{*}{ 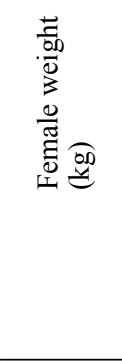 } & \multirow[t]{2}{*}{ 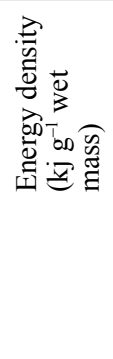 } & \multirow[t]{2}{*}{ 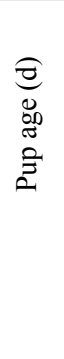 } & \multirow[t]{2}{*}{ 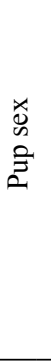 } & \multicolumn{2}{|c|}{ 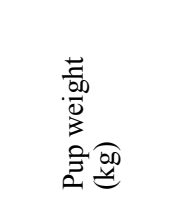 } & \multirow[t]{2}{*}{ 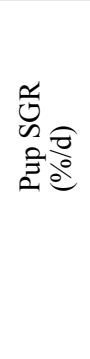 } & \multirow[t]{2}{*}{ 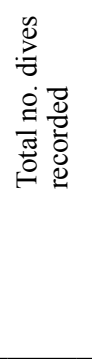 } & \multirow[t]{2}{*}{ 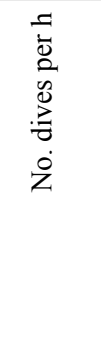 } & \multicolumn{2}{|c|}{ 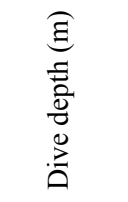 } & \multicolumn{2}{|c|}{ 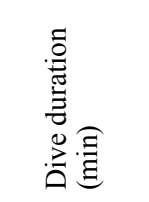 } & \multicolumn{2}{|l|}{ 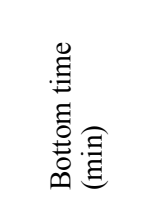 } & \multirow[t]{2}{*}{ 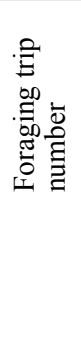 } & \multirow{2}{*}{ 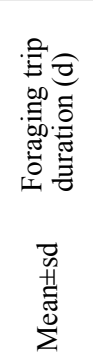 } & \multirow{2}{*}{ 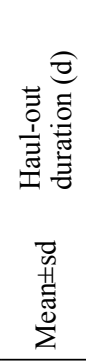 } \\
\hline & & & & & & 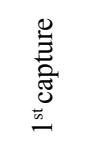 & 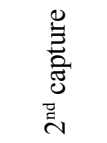 & & & & $\begin{array}{l}\text { D } \\
\text { H } \\
\text { त्ञ } \\
\sum_{\Sigma}^{ \pm}\end{array}$ & 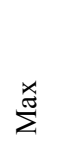 & $\begin{array}{l}\overrightarrow{0} \\
\text { H } \\
\text { ज्ञ } \\
\sum_{\Sigma}\end{array}$ & $\stackrel{\star テ}{\Sigma}$ & 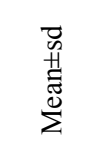 & 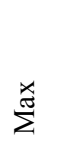 & & & \\
\hline \multirow[t]{7}{*}{ Argentina } & 59 & 86.0 & 13.8 & 14 & q & 11.9 & 14.9 & 0.9 & 3220 & 7.2 & $72 \pm 33$ & 111 & $2.6 \pm 1.2$ & 5.3 & $2.1 \pm 1.1$ & 5.2 & & $2.7 \pm 0.1$ & $1.3 \pm 1.3$ \\
\hline & 64 & 91 & & 13 & q & & 16.4 & 0.9 & 312 & 6.9 & $68 \pm 33$ & 114 & \pm 0.8 & 3. & 0.7 & & & $8 \pm 0.3$ & $2.6 \pm 2.6$ \\
\hline & 70 & 103.4 & 16.4 & 11 & 우 & 11. & 14.9 & 1.1 & 4040 & 8.0 & $60 \pm 36$ & 113 & $1.8 \pm 0.9$ & 4.6 & $.1 \pm 0.7$ & 4.1 & & $.5 \pm 0.4$ & $2.1 \pm 2.1$ \\
\hline & 74 & 98.3 & 13.7 & 12 & $\hat{0}$ & 14. & 15 & 0.4 & 5715 & 10.2 & $47 \pm 40$ & 113 & $1.7 \pm 1.3$ & 7.0 & $3 \pm 1.0$ & 6.8 & & $6 \pm 0.3$ & $1.5 \pm 1.5$ \\
\hline & 76 & 72.3 & 12.2 & 9 & $\hat{0}$ & 12. & 13.3 & 0.4 & 4576 & 9.3 & $53 \pm 34$ & 114 & $1.6 \pm 1.0$ & 4.7 & $1.0 \pm 0.8$ & 4.4 & 7 & $.9 \pm 0.7$ & $1.2 \pm 1.2$ \\
\hline & 78 & $118.3^{1}$ & 15 & 12 & q & 14.4 & 18.4 & 1.0 & 3270 & 8.0 & $62 \pm 35$ & 114 & $2.0 \pm 1.1$ & 5.7 & $.3 \pm 0.9$ & 5.5 & & $0 \pm 0.6$ & $1.7 \pm 1.7$ \\
\hline & 80 & & 15.2 & 14 & q & & 13.8 & 0.6 & 3326 & 6.6 & $66 \pm 36$ & 116 & $2.5 \pm 1.2$ & 6.0 & $1.8 \pm 1.1$ & 5.3 & 0 & $1 \pm 0.7$ & $1.6 \pm 1.6$ \\
\hline Mean total & & $97.3 \pm 15.6$ & $13.8 \pm 1.8$ & $12 \pm 2$ & & $12.7 \pm 1.3$ & $15.4 \pm 1.7$ & $0.8 \pm 0.3$ & 25464 & $8.0 \pm 1.3$ & $59 \pm 37$ & 116 & $2.0 \pm 1.2$ & 7 & $1.3 \pm 1.0$ & 7 & 5 & $2.3 \pm 0.6$ & $1.7 \pm 0.6$ \\
\hline \multirow[t]{7}{*}{ Uruguay } & $\mathrm{H} 2$ & $115.6^{1}$ & 12.8 & 14 & q & & 16 & 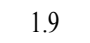 & 8807 & 21.5 & $23 \pm 7$ & 50 & $1.7 \pm 0.5$ & 4.8 & $0.9 \pm 0.4$ & 3.0 & 10 & $.6 \pm 0.8$ & $1.5 \pm 0.5$ \\
\hline & $\mathrm{H} 3$ & $160.2^{1}$ & 12.8 & 15 & 0 & 15.4 & 20.9 & 1.9 & 6332 & 14.4 & $17 \pm 6$ & 35 & $2.1 \pm 0.8$ & 5.0 & $1.2 \pm 0.7$ & 3.8 & 11 & $.7 \pm 0.5$ & $1.2 \pm 0.2$ \\
\hline & H4 & 101.8 & 18.8 & 17 & q & 14.4 & 16.2 & 1.7 & 7824 & 18.8 & $18 \pm 6$ & 35 & $1.7 \pm 0.6$ & 4.2 & $1.1 \pm 0.5$ & 3.5 & ro & $0.7 \pm 0.5$ & $0.7 \pm 0.5$ \\
\hline & $\mathrm{H} 5$ & 97.6 & 11.8 & 12 & q & 12.0 & & & 7605 & 16.1 & $23 \pm 8$ & 57 & $2.1 \pm 0.7$ & 4.6 & $1.3 \pm 0.6$ & 4.0 & 11 & $1.7 \pm 0.8$ & $1.2 \pm 0.7$ \\
\hline & H6 & $120.2^{1}$ & 15.0 & 11 & $\hat{0}$ & 15.2 & 21.3 & 2.2 & 9009 & 19.7 & $23 \pm 8$ & 78 & $1.7 \pm 0.6$ & 4.4 & $0.8 \pm 0.5$ & 3.8 & 20 & $0.9 \pm 0.7$ & $0.9 \pm 0.3$ \\
\hline & $\mathrm{H}$ & $128.2^{1}$ & 18.5 & 14 & $\hat{0}$ & 18.2 & 22.5 & 1.3 & 10001 & 16.1 & $19 \pm 6$ & 36 & $2.1 \pm 0.8$ & 5.4 & $1.2 \pm 0.7$ & 4.0 & 11 & $2.4 \pm 0.8$ & $1.6 \pm 0.8$ \\
\hline & $\mathrm{H} 10$ & $152.2^{1}$ & 17.4 & 16 & o & 15.5 & & & 1269 & 13.9 & $29 \pm 11$ & 55 & $2.5 \pm 0.8$ & 4.8 & $1.3 \pm 0.7$ & 3.5 & 2 & $.9 \pm 0.8$ & 2.6 \\
\hline Mean total & & $125.1 \pm 23.7$ & $15.3 \pm 2.9$ & $14 \pm 2$ & & $14.7 \pm 2.1$ & $19.5 \pm 2.9$ & $1.8 \pm 0.3$ & 7264 & $17.2 \pm 2.8$ & $21 \pm 8$ & 57 & $1.9 \pm 0.7$ & 5 & $1.1 \pm 0.6$ & 4 & 13 & $1.3 \pm 0.9$ & $1.1 \pm 0.7$ \\
\hline
\end{tabular}


cause many pups were captured and bleach-marked at birth for another study. Pups were placed in a jute bag and weighed using a $50 \mathrm{~kg}( \pm 0.1 \mathrm{~kg})$ capacity digital scale, sexed, tagged and then released on the colony. All the females captured in Uruguay were sedated using isoflurane gas mixed with oxygen $(0.5-2.5 \%)$ administered by a portable-field vaporizer (see Riet-Sapriza et al. 2013), whereas all the females captured in Argentina were placed into a cage and sedated using a combination of midazolam 5\% (a benzodiazepine with sedative or tranquilizing action) and dexmedetomidine (a non-narcotic sedative, $\alpha 2$-agonist) administered by intramuscular injection with a dosage of 0.15 to $0.5 \mathrm{mg} \mathrm{kg}^{-1}$ and 0.003 to $0.005 \mathrm{mg} \mathrm{kg}^{-1}$, respectively (Drago et al. 2015, Katz et al. 2018).

Once sedated, each female was weighed with a $300 \mathrm{~kg}( \pm 0.1 \mathrm{~kg})$ capacity digital scale, measured and fitted with a time-depth recorder (TDR Sensus Ultra by ReefNet Inc., Mississauga, ON, Canada, for the females from Argentina; Mk9 by Wildlife Computers Inc., Redmond, WA, USA, for the females from Uruguay) attached to a neoprene patch that was glued to the fur on the upper back using quick-set epoxy. Sensus Ultra and Mk9 TDRs provide comparable diving records (Jeglinski et al. 2012, Robinson et al. 2009) and both types were programmed to sample depth and time every $5 \mathrm{~s}$. The depth resolution and accuracy was $0.5 \pm 0.05 \mathrm{~m}$ for the Mk9 TDRs and $0.1 \pm 0.03 \mathrm{~m}$ for the Sensus Ultra TDRs (Jeglinski et al. 2012, Riet-Sapriza et al. 2013, Robinson et al. 2009).

From each female, we collected $\sim 5 \mathrm{~mL}$ of milk from one or more teats to determine its proximate chemical composition and energy density. Although milk energy density has been documented to change within a single attendance cycle depending on how long the female has been ashore (Georges et al. 2001), we were not able to control for that source of variability. Milk samples were collected by suction using a vacuum pump (20 $\mathrm{mL}$ plastic syringe) positioned over the teat or by manual manipulation of the teat surrounding area. Milk collection was facilitated by an intramuscular injection of oxytocin (60 IU/animal) (Oftedal et al. 1988, Werner et al. 1996), whose effect on milk composition has been deemed negligible (Oftedal et al. 1987, 1988). All milk samples were stored in liquid nitrogen and later in a freezer at $-20^{\circ} \mathrm{C}$ until chemical analysis.

In the second and third week of February, i.e. about $21( \pm 5)$ days after first sampling, the pups were opportunistically recaptured ( 7 from Uruguay and 10 from Argentina) and weighed again to calculate their specific growth rate (SGR). Furthermore, in the same period, we recaptured 7 females from Uruguay and 7 from Argentina to recover the TDRs. In this case, the sedative drug (midazolam 5\% and dexmedetomidine) was administered to sea lion females using a dart (3 $\mathrm{mL}$ ) shot by means of a $\mathrm{CO}_{2}$ Dan-Inject Rifle (Børkop, Denmark). After sedation, females were restrained with a hoop net to allow the removal of the instruments by cutting through the neoprene mounting patch, leaving behind the epoxy mount that would fall off during moulting. The same procedure was followed in the two colonies.

\section{Milk composition analysis}

We analysed the proximate chemical composition (water, lipids, proteins and ash content) of 22 milk samples (10 from Uruguay and 12 from Argentina) and used that information to calculate total milk energy density. In the laboratory, frozen milk samples were immersed in warm water $\left(40-50^{\circ} \mathrm{C}\right)$ to promote rapid thawing and minimize phase separation (Oftedal et al. 2014). After thawing, milk samples were thoroughly mixed before removal of each aliquot $(\sim 1 \mathrm{~mL})$ for analysis.

Samples were weighed and dried in an oven at $100^{\circ} \mathrm{C}$ until a constant weight was reached. The moisture content of a subsample was calculated by gravimetric difference between wet and dry mass (International Dairy Federation 1987, Riedman and Ortiz 1979, Werner et al. 1996). Dry samples were homogenized and a subsample was burnt for $5 \mathrm{~h}$ in a muffle furnace at $550^{\circ} \mathrm{C}$ for ash determination (Eisert et al. 2013, Oftedal et al. 2014).

Another subsample was processed to determine its nitrogen content using an elemental analyser. This value was later multiplied by 6.38 to obtain the relative abundance of proteins in the dry material (Barbano et al. 1990, Werner et al. 1996). Lipids were extracted from a third subsample with a chloroform/methanol (2:1) solution (Bligh and Dyer 1959) and their content was determined by the gravimetric difference between fat and non-fat dry mass (Riedman and Ortiz 1979, Werner et al. 1996).

Because carbohydrates are low in South American sea lion female milk (Werner et al. 1996), as well as in other pinnipeds (Kretzmann et al. 1991, Lavigne et al. 1982, Oftedal et al. 1987), and therefore their contribution to the energetic value is negligible, we calculated their content indirectly as the remaining percentage of the total solids content of the milk (i.e. $100 \%$ - total solids percent of the milk).

Finally, milk energy density was calculated assuming energy equivalents of $23.85 \mathrm{kj} \mathrm{g}^{-1}$ for protein and $39.33 \mathrm{kj} \mathrm{g}^{-1}$ for lipid (Kleiber 1975, Werner et al. 1996).

\section{Growth}

The SGR of pups, expressed as the relative body weight gained or lost per day $(\% / d)$, was calculated according to the following equation:

$$
\mathrm{SGR}=\left[\ln \left(W_{t+d} / W_{t 0}\right) / d\right] 100
$$

where $W_{t 0}$ is the initial body weight $(\mathrm{kg})$ of the pup, $W_{t+d}$ is the final body weight $(\mathrm{kg})$ after $d$ days, and $d$ is the number of days between measurements. We choose the SGR because of the big differences in the body mass of males and females at birth (Cappozzo et al. 1991, Drago et al. 2011, Franco-Trecu et al. 2015).

\section{Diving behaviour, time at-sea and haul-out ashore}

The diving behaviour of female sea lions was characterized by the depth, number, duration and bottom time of dive events. The diving information from the 
TDRs was analysed using the diveMove library version 1.2.5 (Luque 2007) of the free software R. The frequency distribution of dive depth was used to determine the maximum depth at which shallow dives occur, following Tremblay and Cherel (2003). Namely, foraging dives were distinguished from travelling dives by assuming the latter consisted of a sequence of shallow dives or "porpoising" $(<5 \mathrm{~m})$, a behaviour characteristic of travelling sea lions (Blake 1983, Williams 2001). According to this approach we defined porpoising or travelling dives as those of less than $5 \mathrm{~m}$ and excluded them from further analysis. The estimation of the duration of foraging trips (time at-sea) and haul-outs (ashore) of lactating females was based on the wet and dry times obtained from the TDRs, which were equipped with a wet/dry sensor set to turn off when dry.

\section{Data analyses}

Data are shown as mean \pm standard deviation (sd) unless otherwise stated, and the significance level considered for all tests was 0.05 . All the statistical analyses were carried out using the free software R 3.4.4 (R Core Team 2018). We used generalized linear mixing models (lme4 package) to assess the effect of descriptive parameters in response variables. For all analyses, we only included numerical explanatory variables having a Pearson correlation smaller than 0.7 (in absolute value) to minimize collinearity between numerical explanatory variables (Dormann et al. 2013). Whenever an initial statistical model contained more than one numerical explanatory variable, we standardized them so as to be able to compare their relative effects on the response variable (Schielzeth 2010).

First, we assessed whether the variables describing the attendance pattern (the average foraging trip and haul-out duration for each female) were related to female mass, capture pup mass and sex as fixed effects and colony as a random effect, using a Gaussian distribution with identity link function for the average foraging trip variable and a Gamma distribution with a log link function for the haul-out duration variable. We chose to use colony as a random effect because differences between colonies were apparent and sample sizes too small to include them as a fixed effect. Second, we assessed whether dive variables (number of dives per $\mathrm{h}$ and average dive and bottom time per female) were related to female mass and pup sex as fixed effects and colony as a random effect. We used a Gaussian distribution to model the dive time and a Gamma distribution to model the bottom time and the number of dives per h. Third, we assessed whether milk energy density was related to the female mass, average duration of foraging trips and haul-outs as fixed effects and colony as a random effect using a Gamma distribution with a log link function. Fourth, we assessed whether pup SGR was related to milk energy density, pup mass and sex, average haul-out and foraging trip duration as fixed effects and colony as a random effect using Gamma distribution with a $\log$ link function. Although female and pup body mass were highly correlated (0.77), in the statistical models we included both variables, depending on which of them were more appropriate biologically. For all variables analysed, the best probability distribution for the response variables were selected by comparing the corrected Akaike information criterion among candidate distributions using the fitdistrplus package (Delignette-Muller and Dutang 2015).

For all analyses, we first fitted the initial statistical generalized mixing models described above for each response variable and proceeded to simplify each of these models by sequentially deleting one term (be it an interaction or a main effect) and comparing pairs of models differing by only one term using the likelihood ratio tests of models (Bolker 2008). This procedure of model selection allowed the sequential simplification of the initial statistical models to reach the most parsimonious model that can be fitted to each dataset. All final statistical models were validated by a residual analysis to verify the fulfilment of the assumptions of the generalized linear models.

\section{RESULTS}

We collected data from 14 females ranging in body mass from 72.3 to $160.2 \mathrm{~kg}$ (Table 1). At first capture, male pups ranged from 12.1 to $18.2 \mathrm{~kg}$ and female pups from 11.3 to $15.5 \mathrm{~kg}$. The number of dives per $\mathrm{h}$ ranged from 6.6 to 21.5 (Table 1). The average duration of the female foraging trips ranged from $0.7 \pm 0.5$ to $2.8 \pm 0.3$ days, and the average of haul-out lasted from $0.7 \pm 0.5$ to $2.6 \pm 2.6$ days (Table 1 ). The average dive time ranged from $1.7 \pm 0.6$ to $2.6 \pm 1.2$ minutes and the average bottom time ranged from $0.8 \pm 0.5$ to $2.1 \pm 1.1$ minutes. The average duration of the female foraging trips was explained by a model including only pup mass and sex and their interaction (Table 2). It should be noted that the selected model explained $71 \%$ of the deviance, although most of the deviance (51\%) was explained by

Table 2. - Effects of explanatory variables on the average duration of foraging trips and haul-outs of female South American sea lions from breeding colonies in Uruguay (Isla de Lobos) and Argentina (Isla Arce), according to generalized linear mixed model with Gaussian and Gamma distribution, respectively.

\begin{tabular}{lccc}
\hline & Estimate & SE & P \\
\hline Foraging trips & & & \\
Intercept & 1.89 & 0.40 & 0.045 \\
Pup mass & -0.18 & 0.29 & 0.543 \\
Pup sex (male) & -0.35 & 0.30 & 0.261 \\
Pup mass*Pup sex & 0.81 & 0.35 & 0.044 \\
Haul-outs & & & \\
Intercept & 0.34 & 0.23 & 0.130 \\
Pup mass & -0.15 & 0.17 & 0.390 \\
Pup sex (male) & -0.30 & 0.17 & 0.080 \\
Pup mass*Pup sex & 0.44 & 0.20 & 0.030 \\
\hline
\end{tabular}



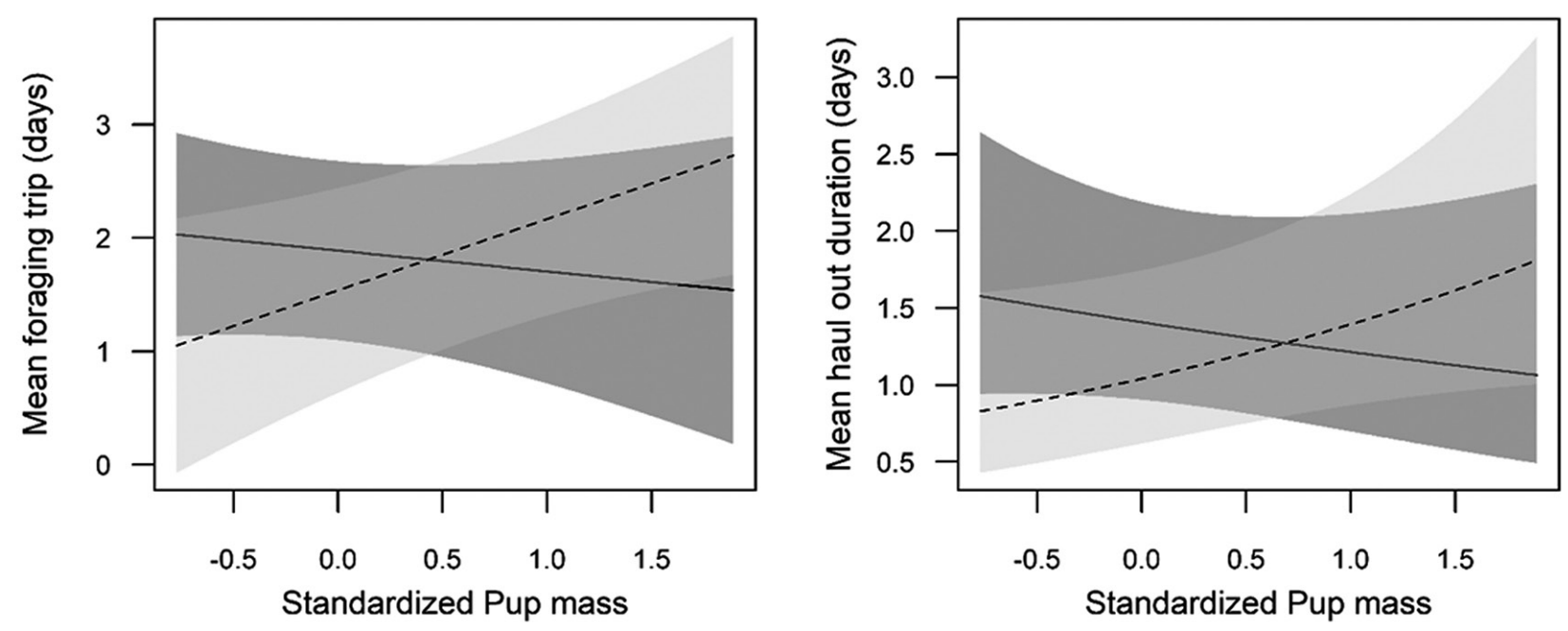

Fig. 2. - Average duration of the female foraging trips (left) and of haul-outs (right) in relation to the standardized mass of South American sea lion pups. The curves were obtained by fitting a generalized linear model with Gamma distribution with a log link function, and the shaded areas are the $95 \%$ confidence intervals for each variable (see main text and Table 2 for details). Dashed curves are for male pups and solid lines for female pups.

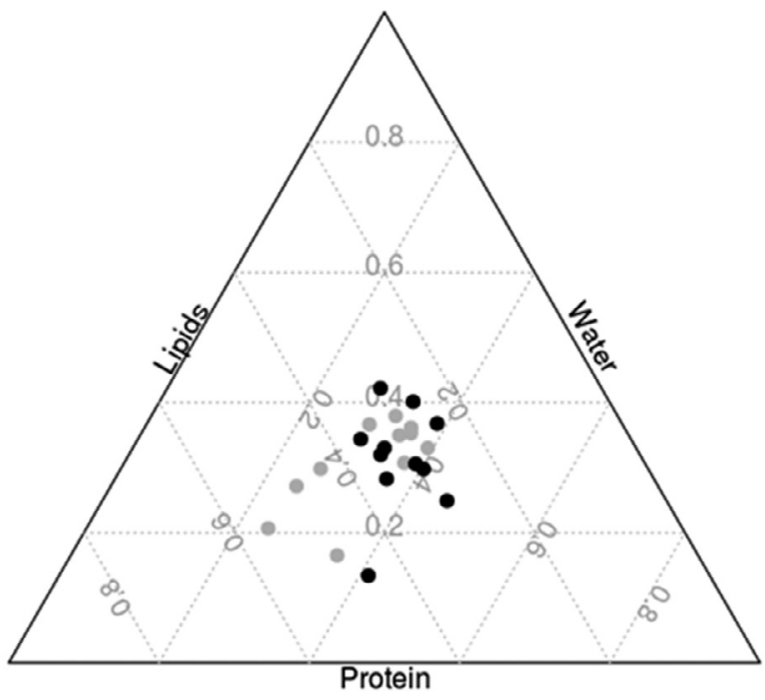

Fig. 3. - Ternary plot of the relative composition in lipids, protein and water of the milk of South American sea lion females in Isla Arce, Argentina (black) and Isla de Lobos, Uruguay (grey). The other two components of milk (carbohydrates and ash) accounted for less than $1.5 \%$ in weight of the milk composition.

the random effect of colony. The pup mass*sex interaction term in the selected model was significant because the weight of female pups had a negligible influence on the average duration of females' foraging trips, whereas females with heavier male pups were involved in longer foraging trips (Fig. 2).

As above, the best model for explaining average haul-out duration included only pup mass and sex and their interaction (Table 2). The statistically significant interaction term resulted from the opposite relationship between haul-out duration and pup mass for female and male pups (Fig. 2). As above, the random colony effect explained a large part of the

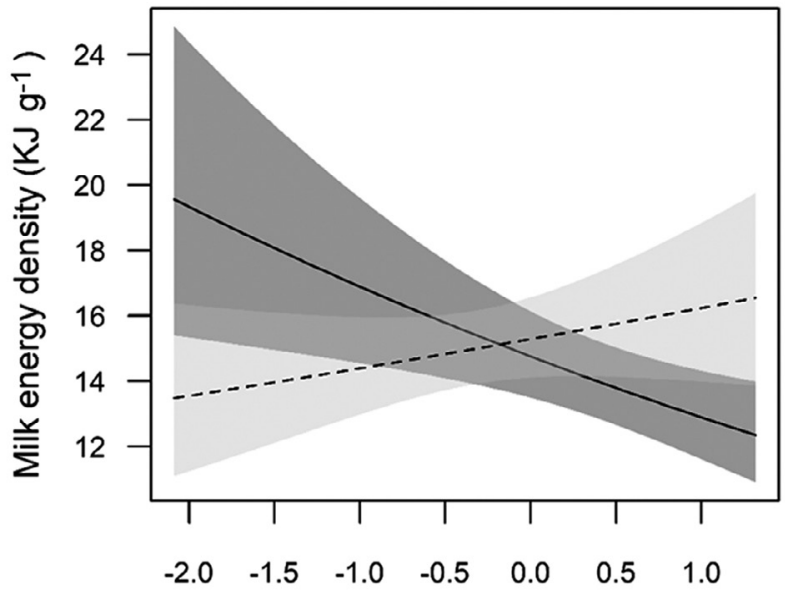

Standardized mean foraging trip (days)

Fig. 4. - Standardized average duration of the South American sea lion female foraging trips and female mass (dashed line, females heavier than average; solid line, females lighter than average) in relation to the milk energy density. The curves were obtained by fitting a generalized linear model with Gamma distribution with a log link function. The shaded areas are the $95 \%$ confidence intervals for each variable.

total deviance explained by the model $(21.6 \%$ out of $47 \%$ ). Dive descriptors (dive time, bottom time and dives per $\mathrm{h}$ ) were not affected significantly by female body mass or pup sex. The random colony effect did not increase the total deviance explained by dive descriptor models.

The average milk contents, on a wet weigh basis, was $54.8 \%$ water, $28.7 \%$ lipids, $14.2 \%$ proteins, $2.1 \%$ ash and $0.3 \%$ carbohydrates (Fig. 3). The resulting average energy density was $14.7 \mathrm{kj} \mathrm{g}^{-1}$, and the model selected to explain the variability of milk energy density across females included female mass, the average duration of foraging trips and their interaction (Table 3 ). 
Table 3. - Effects of potential explanatory variables on the milk energy density ( $\mathrm{kJ} \mathrm{g}^{-1}$ wet mass) of South American sea lion females from Isla de Lobos (Uruguay) and Isla Arce (Argentina) according to a general linear mixed model.

\begin{tabular}{lccc}
\hline & Estimate & $\mathrm{SE}$ & $\mathrm{P}$ \\
\hline Intercept & 2.70 & 0.03 & $<0.001$ \\
Female mass & 0.06 & 0.03 & 0.101 \\
Avg. duration foraging trips & 0.01 & 0.03 & 0.918 \\
Female mass $\times$ duration trips & 0.15 & 0.07 & 0.034 \\
\hline
\end{tabular}

The female mass*trip duration interaction term was significant because larger females produced milk with a higher energy density after long trips, whereas the opposite was true for smaller females (Fig. 4). It should be noted that a single specimen involved in very short foraging trips, but producing high energy milk had a disproportionate impact on the pattern of females with a body mass below the average.

Finally, the only statistically significant model for pup SGR contained only pup sex and showed that the SGR was significantly higher for female pups (Male: mean $=1.098$ day $^{-1}$, Female: mean $=1.253$ day $^{-1}$; $\mathrm{p}=0.011$ ), with no statistically significant effect of milk energy density, pup mass or the average duration of foraging trips and haul-outs. Again, the random effect of colony substantially increased the deviance explained by the model ( $33 \%$ out of $62 \%)$.

\section{DISCUSSION}

The results reported here revealed no significant effect of the female attendance pattern on pup growth rate, but a strong effect of pup sex and pup mass on female foraging behaviour. This is because females with male pups were involved in longer foraging trips and longer haul-outs than females with female pups. Furthermore, longer foraging trips resulted in the production of more energetic milk, but only for heavier females. Distribution of heavier females was uneven between colonies, as only one female from Argentina but five from Uruguay were heavier than average. However, pup growth rate was independent of milk energy density or haul-out duration, with male pups growing more slowly than female pups. The overall evidence suggests that, during the first three weeks of the lactation period, female South American sea lions balance the duration of the foraging trips and haul-outs according to the demands of their pups, which probably depend on pup body mass and sex. As a result, pup growth rate is independent of the attendance pattern and the energy density of milk. However, caution is needed, and all the results should be considered as an approximation because of the small sample size.

Longer foraging trips may be due to at least three different reasons: a lower foraging efficiency (Jeanniard du Dot et al. 2017), exploitation of closer patches with low food density (Soto et al. 2006) or targeting more distant foraging grounds with high food density (Jeanniard du Dot et al. 2018, McHuron et al. 2016). Foraging trip durations have been negatively correlated with pup growth rate in the two former scenarios (Gentry and Kooyman 1986, Georges and Guinet 2000, Jeanniard du Dot et al. 2017), but positively correlated in the third scenario (Arnould and Hindell 1999, Jeanniard du Dot et al. 2018, McHuron et al. 2016). Nevertheless, access to distant foraging grounds is profitable only for females with high energy reserves, which may explain why in this study longer foraging trips resulted in milk with a higher energy density only for females that are heavier than average. However, we did not satellite track the foraging trips in Isla Arce (Argentina) and hence cannot verify whether females involved in longer foraging trips actually used the highly productive front over the shelf break (Fig. 1).

A longer foraging time resulting from aiming at highly productive but distant foraging grounds results in less frequent haul-outs, which must be compensated with increased milk energy density or total milk delivery. Here we assessed the quality of the milk delivered and the maternal attendance pattern, but not the total amount of milk delivered to the pup. Furthermore, milk energy density can decrease by $\sim 5 \%$ throughout a single attendance cycle, depending on how long the female has been ashore and the pups' age (Georges et al. 2001). Unfortunately, we collected milk samples opportunistically and hence were unable to control for the stage of the attendance cycle. Nevertheless, female foraging efficiency does not seem to be relevant during the first three weeks of nursing, because no relationship was found in the studied populations between pup growth rate and the attendance pattern. Female foraging efficiency may become more relevant as pups grow and females need to supply them with more milk (Georges and Guinet 2000, Jeanniard du Dot et al. 2017).

Unlike trip durations, the number of dives per $h$, average diving time and average bottom time were independent from all explanatory variables considered. South American sea lions seldom dive longer than their aerobic dive limit and hence dive duration is strongly determined by their total oxygen stores (Hückstädt et al. 2016). There is no information on the oxygen stores of South American sea lions from northern Patagonia, but the oxygen stores of South American sea lions from Uruguay and the Falkland Islands are fairly similar despite differences in body mass (Hückstädt et al. 2016). Thus, the absence of any effect of female body size on average dive time and average bottom time reported in this study is no surprise.

It should be noted that colony had a strong random effect on some of the response variables analysed here. Although the study design confounded colony and year, it is worth exploring the potential causes of that effect. The growth and survival rates of otariid pups is largely dependent on both environmental conditions (Reid and Forcada 2005, Soto et al. 2004, Trillmich and Limberger 1985) and stress caused by social interactions, with colony size as a major determinant of the strength of social interactions in the South American 
sea lion (Cassini and Fernández-Juricic 2003, Drago et al. 2011). The study was conducted in two reproductive areas containing a total of 180 (Isla de Lobos) and 150 individuals (Isla Arce) of both sexes and all development stages, but population density was higher in Isla de Lobos (2926 sea lions $\mathrm{km}^{-2}$ ) than in Isla Arce (2000 sea lions $\mathrm{km}^{-2}$ ) when the whole rookeries are considered. Pup SGR was expected to be lower at the more densely populated site (Isla de Lobos) if social stress was the causal factor for the strong colony/ year effect observed in the present study, as reported in previous studies (Drago et al. 2011). However, the opposite was true, and pups from Isla de Lobos grew faster than those from Isla Arce. This suggests, but does not prove, that differences in environmental conditions determining differences in food availability for females may explain the strong colony/year effect observed in the present study.

Marine primary productivity is a major determinant of otariid pup growth and survival worldwide (Lunn et al. 1994, Reid and Forcada 2005, Soto et al. 2004), and populations of the same species inhabiting areas of contrasting primary productivity are expected to differ in pup production. Females breeding at Isla de Lobos (Uruguay) prey on large demersal fishes (Franco-Trecu et al. 2013) on the continental shelf within a few kilometres of the rookery (Franco-Trecu et al. 2019, Riet-Sapriza et al. 2013, Rodriguez et al. 2013). These foraging grounds are adjacent to the highly productive plume of Río de la Plata (Acha et al. 2008, Fig. 1). Horizontal tracking data are lacking for females from Isla Arce (Argentina), but the females from other rookeries in northern Patagonia less than $300 \mathrm{~km}$ north of Isla Arce have similar at-sea and haul-out times and forage both nearshore and offshore (Campagna et al. 2001) to capture a mixture of demersal and pelagic prey (Drago et al. 2009, 2010b, Koen-Alonso et al. 2000). However, the pups of females relying more heavily on pelagic offshore fishes grow faster (Drago et al. 2010a), although accessing the frontal system over the continental shelf may require longer foraging trips.

Primary productivity off Patagonia is highly variable, with several frontal areas of enhanced productivity (Rivas et al. 2006), but overall the habitat is more heterogeneous and less productive than Río de la Plata (Fig. $1)$. The average duration of female foraging trips and haul-outs at Isla Lobos (Uruguay) in 2009 appeared shorter than those observed at Isla Arce (Argentina) in 2015, which in turn were similar to those observed previously in other rookeries from northern Patagonia (Campagna et al. 2001). Furthermore, females from Isla Arce (Argentina) in 2015 spent ashore only $66 \%$ of the time spent by females at Isla de Lobos (Uruguay) in 2009 during the three weeks covered by the study period. In parallel, pups at Isla Arce (Argentina) in 2015 grew more slowly than those at Isla de Lobos (Uruguay) in 2009 (Table 1). This suggests that the longer foraging trips observed in Argentina (Campagna et al. 2001, this study) and the slower growth rate of pups could be the consequence of a lower prey availability and a higher cost of capture (Jeanniard du Dot et al. 2017, 2018, Soto et al. 2006) in Argentina than in Uru- guay. However, simultaneous sampling in Uruguay and Argentina over several years and location data are required to confirm this hypothesis.

The results reported here revealed that pup sex and mass are the major determinant of female foraging and haul-out behaviour, which is likely related to the higher body mass of male pups. Furthermore, individual differences in the duration of foraging trips and haulout are of little significance for explaining the growth rate of pups. Temporal or regional differences in prey availability are probably more relevant, although further research is necessary to account for temporal and geographic variability in food availability.

\section{ACKNOWLEDGEMENTS}

We thank L. Olivera, N. Veiga, M. Casela, D.P. Costa, D.J. Shuman, H. Katz and the staff of the Marine Mammal Laboratory of the Centro Nacional Patagónico (CENPAT-CONICET), particularly G.M. Svendsen, R. González, N. Sueyro, M. Coscarella and S. Ameghino, for overall assistance and logistic support during fieldwork in Uruguay and Argentina. We also thank L. Reisfeld of the São Paulo Aquarium for veterinary assistance during fieldwork in Argentina. We also thank the two anonymous referees for their careful revision and useful comments to improve the manuscript. The research that gave rise to the results presented in this publication was funded by the $\mathrm{Na}$ tional Agency for Research and Innovation, ANII-Uruguay (PD_NAC_2013_1_10382), the ONG Yaqu-pacha (Germany), the Zoo d'Amneville (France) and the Agencia Nacional de Promoción Cientifica y Tecnologica (PICT 2110).

All procedures of animal manipulation were submitted to and approved by the Ethics Committee in Animal Experimentation of the University of the Republic (Uruguay) and the Centro Nacional Patagónico (Argentina) according to the national laws on animal welfare. The fieldwork and sampling were authorized by the National Council for Aquatic Resources, Ministry of Livestock, Agriculture and Fishing (DINARA, Uruguay) under permit No 572/2008 and the National Park Administration (APN, Argentina) under permit No 1340 APN. The authors declare that they have no conflict of interest.

\section{REFERENCES}

Acha E.M., Mianzan H., Guerrero R., et al. 2008. An overview of physical and ecological processes in the Rio de la Plata Estuary. Cont. Shelf Res. 28: 1579-1588. https://doi.org/10.1016/j.csr.2007.01.031

Arnould J.P.Y., Boyd I.L. 1995. Temporal patterns of milk production in Antarctic fur seal (Arctocephalus gazella). J. Zool. 237: 1-12. https://doi.org/10.1111/j.1469-7998.1995.tb02741.x

Arnould J.P.Y., Hindell M.A. 1999. The composition of Australian fur seal (Arctocephalus pusillus doriferus) milk throughout lactation. Physiol. Biochem. Zool. 72: 605612 .

https://doi.org/10.1086/316702

Arnould J.P.Y., Boyd I.L., Speakman J.R. 1996. The relationship between foraging behaviour and energy expenditure in Antarctic fur seals. J. Zool. 239: 769-782.

https://doi.org/10.1111/j.1469-7998.1996.tb05477.x 
Barbano D.M., Clark J.L., Chapman E.D., et al. 1990. Kjeldahl method for determination of total nitrogen content of milk: Collaborative study. J. Assoc. Off. Anal. Chem. 73: 849-859. https://doi.org/10.1093/jaoac/73.6.849

Blake R. 1983. Energetics of leaping in dolphins and other aquatic animals. J. Mar. Biol. Assoc. UK 63: 61-70. https://doi.org/10.1017/S0025315400049808

Bligh E.G., Dyer W.J. 1959. A rapid method of total lipid extraction and purification. Can. J. Biochem. Physiol. 37: 911-917. https://doi.org/10.1139/y59-099

Bolker B.M. 2008. Ecological models and data in R. Princeton University Press, Princeton, 408 pp.

Boyd I.L., Arnould J.P.Y., Barton T., et al. 1994. Foraging behaviour of Antarctic fur seals during periods of contrasting prey abundance. J. Anim. Ecol. 63: 703-713. https://doi.org/10.2307/5235

Campagna C., Bisioli C., Quintana F., et al. 1992. Group breeding in sea lions: pups survive better in colonies. Anim. Behav. 43: 541-548. https://doi.org/10.1016/S0003-3472(05)81014-0

Campagna C., Werner R., Karesh W., et al. 2001. Movements and locations at sea of South American sea lions (Otaria flavescens). J. Zool. 257: 205-220. https://doi.org/10.1017/S0952836901001285

Cappozzo H.L., Perrin W.P. 2009. South American sea lion (Otaria flavescens). In: Perrin W.F., Würsing B., Thewissen J.G.M. (eds), Encyclopedia of Marine Mammals (2nd ed.). Academic Press, pp. 1076-1079. https://doi.org/10.1016/B978-0-12-373553-9.00244-3

Cappozzo H.L., Campagna C., Monserrat J. 1991. Sexual dimorphism in newborn Southern sea lions. Mar. Mamm. Sci. 7: 385-394. https://doi.org/10.1111/j.1748-7692.1991.tb00113.x

Cassini M.H., Fernández-Juricic E. 2003. Costs and benefits of joining South American sea lion breeding groups: testing the assumptions of a model of female breeding dispersion. Can. J. Zool. 81: 1154-1160. https://doi.org/10.1139/z03-098

Clutton-Brock T. 1991. The evolution of parental care. Princeton University Press, Princeton $368 \mathrm{pp}$. https://doi.org/10.1515/9780691206981

Costa D.P. 2008. A conceptual model of the variation in parental attendance in response to environmental fluctuation: Foraging energetics of lactating sea lions and fur seals. Aquatic Conserv.: Mar. Freshw. Ecosyst. 17: S44-S52. https://doi.org/10.1002/aqc.917

Costa D.P., Gales N.J. 2000. Foraging energetics and diving behavior of lactating New Zealand sea lions, Phocarctos hookeri. J. Exp. Biol. 203: 3655-3665

Davies N.B., Krebs J.R., West S.A. 2012. An introduction to behavioural ecology. Wiley-Blackwell Oxford. $520 \mathrm{pp}$.

Delignette-Muller M.L., Dutang C. 2015. Fitdistrplus: an R package for fitting distributions. J. Stat. Softw. 64: 1-34. https://doi.org/10.18637/jss.v064.i04

Dormann C.F., Elith J., Bacher S., et al. 2013. Collinearity: a review of methods to deal with it and a simulation study evaluating their performance. Ecography 36: 27-46. https://doi.org/10.1111/j.1600-0587.2012.07348.x

Drago M., Crespo E.A., Aguilar A., et al. 2009. Historic diet change of the South American sea lion in Patagonia as revealed by isotopic analysis. Mar. Ecol. Prog. Ser. 384: 273286. https://doi.org/10.3354/meps08017

Drago M., Cardona L., Aguilar A., et al. 2010a. Diet of lactating South American sea lions, as inferred from stable isotopes, influences pup growth. Mar. Mamm. Sci. 26: 309-323. https://doi.org/10.1111/j.1748-7692.2009.00321.x

Drago M. Cardona L., Crespo E.A., et al. 2010b. Change in the foraging strategy of female South American sea lions (Carnivora: Pinnipedia) after parturition. Sci. Mar. 74: 589-598. https://doi.org/10.3989/scimar.2010.74n3589

Drago M., Cardona L., García N., et al. 2011. Influence of colony size on pup fitness and survival in South American sea lions. Mar. Mamm. Sci. 27: 167-181. https://doi.org/10.1111/j.1748-7692.2010.00402.x

Drago M., Franco-Trecu V., Cardona L., et al. 2015. Diet-to-female and female-to-pup isotopic discrimination in South American sea lions. Rapid Commun. Mass Spectrom. 29: $1513-1520$.

https://doi.org/10.1002/rcm.7249
Eisert R., Oftedal O.T., Barrell G.K. 2013. Milk composition in the Weddell seal (Leptonychotes weddellii): Evidence for a functional role of milk sugar in pinnipeds. Physiol. Biochem. Zool. 86: 159-175.

https://doi.org/10.1086/669036

Franco-Trecu V. 2015. Tácticas comportamentales de forrajeo y apareamiento y dinámica poblacional de dos especies de otáridos simpátricas con tendencias poblacionales contrastantes. Ph.D. thesis, Universidad de la República, Montevideo, $237 \mathrm{pp}$.

Franco-Trecu V., Drago M., Riet-Sapriza F.G., et al. 2013. Bias in diet determination: Incorporating traditional methods in Bayesian mixing models. PLoS One 8: e80019. https://doi.org/10.1371/journal.pone.0080019

Franco-Trecu V., Drago M., Baladán C., et al. 2015. Postharvesting population dynamics of the South American sea lion (Otaria byronia) in the southwestern Atlantic. Mar. Mamm. Sci. 31: $963-978$ https://doi.org/10.1111/mms.12197

Franco-Trecu V., Szephegyi M.N., Doño F., et al. 2019. Marine mammal bycatch by the industrial bottom trawl fishery at the Río de la Plata Estuary and the adjacent Atlantic Ocean. Lat. Am. J. Aquat. Res. 47: 89-101. https://doi.org/10.3856/vol47-issue1-fulltext-10

Gales N.J., Costa D.P., Kretzmann M. 1996. Proximate composition of Australian sea lion milk throughout the entire supra-annual lactation period. Aust. J. Zool. 44: 651-657. https://doi.org/10.1071/ZO9960651

Gentry R.L. 2009. Eared Seals Otariidae. In: Perrin W.F., Würsing B., Thewissen J.G.M. (eds), Encyclopedia of marine mammals, second edition ed. Academic Press, pp. 339-342. https://doi.org/10.1016/B978-0-12-373553-9.00083-3

Gentry R.L., Kooyman G.L. 1986. Fur seals: maternal strategies on land and at sea. Princeton University Press, New Jersey, 312 pp. https://doi.org/10.1515/9781400854691

Gentry R.L., Costa D.P., Croxall J.P., et al. 1986. Synthesis and conclusion. In: Gentry R.L., Kooyman G.L. (eds), Fur seals: maternal strategies on land and at sea. Princeton University Press, pp. 220-264 https://doi.org/10.1515/9781400854691

Georges J.Y., Guinet C. 2000. Maternal care in the subantarctic fur seals on Amsterdam Island. Ecology 81: 295-308. https://doi.org/10.1890/0012-9658(2000)081[0295:MCITS $\mathrm{F} 2$ 2.0.CO;2

Georges J.Y., Groscolas R., Guinet C., et al. 2001. Milking strategy in subantarctic fur seals Arctocephalus tropicalis breeding on Amsterdam Island: evidence from changes in milk composition. Physiol. Biochem. Zool. 74: 548-559. https://doi.org/10.1086/322164

Guinet C., Goldsworthy S.D., Robinson S. 1999. Sex differences in mass loss rate and growth efficiency in Antarctic fur seal (Arctocephalus gazella) pups at Macquarie Island. Behav. Ecol. Sociobiol. 46: 157-163. https://doi.org/10.1007/s002650050605

Higgins L.V., Gass L. 1993. Birth to weaning: parturition, duration of lactation, and attendance cycles of Australian sea lions (Neophoca cinerea). Can. J. Zool. 71: 2047-2055. https://doi.org/10.1139/z93-290

Hückstädt L.A., Tift M.S., Riet-Sapriza F., et al. 2016. Regional variability in diving physiology and behavior in a widely distributed air-breathing marine predator, the South American sea lion Otaria byronia. J. Exp. Biol. 219: 2320-2330. https://doi.org/10.1242/jeb.138677

International Dairy Federation. 1987. International Standard IDF 21B:1987 (=ISO 6731:1989). Milk, cream and evaporated milk: determination of total solids content (reference method). International Dairy Federation, Brussels.

Jeanniard du Dot T., Trites A.W., Arnould J.P.Y., et al. 2017. Reproductive success is energetically linked to foraging efficiency in Antarctic fur seals. PLoS ONE 12: e0174001. https://doi.org/10.1371/journal.pone.0174001

Jeanniard du Dot T., Trites A.W., Arnould J.P.Y., et al. 2018. Trade-offs between foraging efficiency and pup feeding rate of lactating northern fur seals in a declining population. Mar. Ecol. Prog. Ser. 600: 207-222. https://doi.org/10.3354/meps12638

Jeglinski J.W.E., Werner C., Robinson P.W., et al. 2012. Age, body mass and environmental variation shape the foraging ontogeny of Galapagos sea lions. Mar. Ecol. Prog. Ser. 453: 279-296. https://doi.org/10.3354/meps09649 
Katz H., Reisfeld L., Franco-Trecu V. 2018. Chemical immobilization protocols in free-ranging South American fur seal (Arctocephalus australis) and adult female South American sea lion (Otaria byronia). Mar. Mamm. Sci. 35: 327-335. https://doi.org/10.1111/mms.12524

Kleiber M. 1975. The fire of life. Krieger Publishing Co. Inc., New York.

Koen-Alonso M., Crespo E.A., Pedraza S.N. 2000. Food habits of the South American sea lion, Otaria flavescens, off Patagonia, Argentina. Fish. Bull. 98: 250-263.

Kretzmann M.B., Costa D.P., Higgins L.V., et al. 1991. Milk composition of Australian sea lions, Neophoca cinerea: variability in lipid content. Can. J. Zool. 69: 2556-2561. https://doi.org/10.1139/z91-360

Lavigne D.M., Stewart R.E.A., Fletcher F. 1982. Changes in composition and energy content of harp seal milk during lactation. Physiol. Zool. 55: 1-9. https://doi.org/10.1086/physzool.55.1.30158438

Lunn N.J., Boyd I.L., Croxall J.P. 1994. Reproductive performance of female Antarctic fur seals: The influence of age, breeding experience, environmental variation and individual quality. J. Anim. Ecol. 63: 827-840. https://doi.org/10.2307/5260

Luque S.P. 2007. Diving behaviour analysis in R. R News 7: 8-14.

McHuron E.A., Robinson P.W., Simmons S.E., et al. 2016. Foraging strategies of a generalist marine predator inhabiting a dynamic environment. Oecologia 182: 995-1005. https://doi.org/10.1007/s00442-016-3732-0

Miloslavich P., Klein E., Díaz J.M., et al. 2011. Marine biodiversity in the Atlantic and Pacific coasts of South America: knowledge and gaps. PLoS One 6: e14631. https://doi.org/10.1371/journal.pone.0014631

NASA. 2018. Moderate-resolution imaging spectroradiometer (MODIS) aqua chlorophyll data; 2018 reprocessing. NASA OB.DAAC, Greenbelt, MD, USA.

Oftedal O.T., Boness D.J., Tedman R.A. 1987. The behavior, physiology, and anatomy of lactation in the pinnipedia. In: Genoways H.H. (ed), Current Mammalogy. Plenum Publishing Corporation, pp. 175-245. https://doi.org/10.1007/978-1-4757-9909-5 6

Oftedal O.T., Boness D.J., Bowen W.D. 1988. The composition of hooded seal (Cystophora cristata) milk: an adaptation for postnatal fattening. Can. J. Zool. 66: 318-322. https://doi.org/10.1139/z88-047

Oftedal O.T., Eisert R., Barrell G.K. 2014. Comparison of analytical and predictive methods for water, protein, fat, sugar, and gross energy in marine mammal milk. J. Dairy Sci. 97: 4713-4732. https://doi.org/10.3168/jds.2014-7895

R Core Team. 2018. R: A language and environment for statistical computing. R Foundation for Statistical Computing, Vienna.

Reid K., Forcada J. 2005. Causes of offspring mortality in the Antarctic fur seal, Arctocephalus gazella: the interaction of density dependence and ecosystem variability. Can. J. Zool. 83: 604-609. https://doi.org/10.1139/z05-045
Riedman M., Ortiz C.L. 1979. Changes in milk composition during lactation in the northern elephant seal. Physiol. Zool. 52: $240-249$

https://doi.org/10.1086/physzool.52.2.30152567

Riet-Sapriza F.G., Costa D.P., Franco-Trecu V., et al. 2013. Foraging behavior of lactating South American sea lions, Otaria flavescens and spatial-resource overlap with the Uruguayan fisheries. Deep Sea Res. II 88-89: 106-119. https://doi.org/10.1016/j.dsr2.2012.09.005

Rivas A.L., Dogliotti A.I., Gagliardini D.A. 2006. Seasonal variability in satellite-measured surface chlorophyll in the patagonian shelf. Cont. Shelf Res. 26: 703-720. https://doi.org/10.1016/j.csr.2006.01.013

Robinson P.W., Villegas-Amtmann S., Costa D.P. 2009. Field validation of an inexpensive time-depth recorder. Mar. Mamm. Sci. 25: 199-205. https://doi.org/10.1111/j.1748-7692.2008.00227.x

Rodriguez D.H., Dassis M., de Leon A.P., et al. 2013. Foraging strategies of Southern sea lion females in the La Plata River Estuary (Argentina-Uruguay). Deep Sea Res. II 88-89: 120130 https://doi.org/10.1016/j.dsr2.2012.07.012

Schielzeth H. 2010. Simple means to improve the interpretability of regression coefficients. Methods Ecol. Evol. 1: 103113 https://doi.org/10.1111/j.2041-210X.2010.00012.x

Schulz T.M., Bowen W.D. 2004. Pinniped lactation strategies: evaluation of data on maternal and offspring life history traits. Mar. Mamm. Sci. 20: 86-114. https://doi.org/10.1111/j.1748-7692.2004.tb01142.x

Soto K.H., Trites A.W., Arias-Schreiber M. 2004. The effects of prey availability on pup mortality and the timing of birth of South American sea lions (Otaria flavescens) in Peru. J. Zool. 264: 419-428. https://doi.org/10.1017/S0952836904005965

Soto K.H., Trites A.W., Arias-Schreiber M. 2006. Changes in diet and maternal attendance of South American sea lions indicate changes in the marine environment and prey abundance. Mar. Ecol. Prog. Ser. 312: 277-290. https://doi.org/10.3354/meps312277

Tremblay Y., Cherel Y. 2003. Geographic variation in the foraging behaviour, diet and chick growth of rockhopper penguins. Mar. Ecol. Prog. Ser. 251: 279-297. https://doi.org/10.3354/meps251279

Trillmich F. Limberger D. 1985. Drastic effects of El Niño on Galapagos ecuador pinnipeds. Oecologia 67: 19-22. https://doi.org/10.1007/BF00378445

Webber M.A. 2014. Family Otariidae (Eared seals). In: Wilson D.E., Mittermeier R.A. (eds), Handbook of the mammals of the world. Lynx Ediciones, pp. 34-101.

Werner R., Figueroa-Carranza A., Ortiz C.L. 1996. Composition and energy content of milk from southern sea lions (Otaria flavescens). Mar. Mamm. Sci. 12: 313-317. https://doi.org/10.1111/j.1748-7692.1996.tb00583.x

Williams T. 2001. Intermittent swimming by mammals: a strategy for increasing energetic efficiency during diving. Am. Zool. 41: 166-176. https://doi.org/10.1093/icb/41.2.166 